\title{
The influence of e-word-of-mouth on hotel occupancy rate
}

\begin{abstract}
Purpose - Online reviews have become increasingly important for customer decisionmaking. The hotel industry represents a noticeable case. Consumer reviews posted on websites such as Bookings.com, TripAdvisor, and Venere.com play a critical role in consumers' choice of a hotel. For this reason a number of recent studies analyses different aspects of online reviews. The purpose of this paper is to investigate their effects in terms of hotel occupancy rates.

Design/methodology/approach - The paper measures through regression analysis the impact of three dimensions of consumer reviews (i.e. review score, review variance and review volume) on the occupancy rates of 346 hotels located in Rome, isolating a number of other factors that might also affect demand.

Findings - Review score is the dimension with the highest impact. The results suggest that, after controlling for other variables, a one-point increase in the review score is associated to an increase in the occupancy rate by 7.5 percentage points. Regardless the review score, the number of reviews has a positive effect, but with decreasing returns, implying that the higher the number of reviews, the lower the beneficial effect in terms of occupancy rates is.

Practical implications - The findings quantify the strong association of online reviews to occupancy rates suggesting the use of appropriate reputational management systems to increase hotel occupancy and therefore performance.
\end{abstract}


Originality/Value - A major contribution of this paper is its comprehensiveness in analysing the relation between online consumer reviews and occupancy across a heterogeneous sample of hotels.

Keywords: eWOM, occupancy rate, pricing, hotel performance. 


\section{Introduction}

Consumers have very limited direct information on quality for products that are bought sporadically or for products purchased at a distance. For this reason, they often rely on external sources. For a considerable time, professional reviewers were the main external source of information but their reach in large dispersed markets was limited and not perceived as independent by consumers (Mauri and Minazzi, 2013; Sparks et al., 2013). Online usergenerated content has replaced professional reviewers. This new source of information on the one hand offers a richer and more varied set of reviews with a significantly wider coverage of products. In addition, it brings into the framework heterogeneous tastes and standards of the reviewers.

Recent studies have appeared quantifying the influence online reviews can have on the purchases of movies (Dellarocas et al., 2007; Duan et al., 2008), music (Chintagunta et al., 2010) and, to some extent, hotels (Ye et al., 2011; Anderson, 2012; Öğüt and Onur Taş, 2012; Kim et al., 2015a). This paper intends to measure the association of user-generated content (online reviews) to hotel occupancy rates.

The hotel product is a service that is bought in advance of usage, usually without any direct visual evaluation. However, it is significantly more expensive than buying a book or watching a movie. In this regard, consumers spend a substantial amount of time going through reviews, contributing to the success of online review websites such as Tripadvisor, valuated $\$ 13$ billion at the time of writing. Therefore, hotel managers should strive to understand how reviews posted online affect the consumer decision-making process and in turn the effect on hotel performance. Research on the specific impact of the dimensions of online reviews on hotel performance is still limited. Ye et al. (2011) in a first attempt to uncover such relationships used, as a proxy of 
sales, the number of reviews. Recently, Kim et al. (2015a) took the research further by examining the impact of an aggregate measure of online reviews on some financial indicators (RevPar and ADR). Nonetheless, for the challenging task of collecting individual property data from different types of hotels, they obtained data only from hotels of a single company, suggesting further research to measure the generalizability of their findings.

This study proposes an analysis of the association of different sources of eWOM to hotel occupancy rates. Moreover, we introduce a time lag between the online review data collection time and the occupancy rate data collection time, accounting for the misalignment between booking date and check-in date. Occupancy is a performance variable of paramount importance in a sector characterized by perishable assets (Bilotkach et al., 2015) and, compared to other performance measures, using this indicator allows the researchers to measure the elasticity between this volume dimension and a variation of prices (hotel rates).

A set of consumer opinions was obtained from three of the most used online review websites in Italy: Booking.com, Tripadvisor, and Venere.com. The final dataset merges the occupancy levels of 346 hotels in the city of Rome with three dimensions of online reviews (i.e., rating/score, variance and volume) and other control variables.

\section{Literature review}

\section{Word-of-mouth concepts and the Internet}

Before the advent of Information technology, word-of-mouth marketing (WOM) meant a consumer spreading the experience among friends and relatives. Marketing researchers have long studied WOM demonstrating its powerful influence on perceptions, expectations and customer behaviour (Webster, 1991; Zeithaml et al., 1993). WOM can be a source of 
information before the purchase (input WOM) and after the experience (output WOM) (Buttle, 1998). In particular after the experience customers can offer information and recommendations to other people. Coming from peers, WOM is generally considered more credible than advertising (Stern, 1994; Ogden, 2001).

The concept of WOM has changed with the development of the Internet (Buttle, 1998; Cheung and Thadani, 2012). In particular, the increase of social media adoption and online bookings (OTAs) has made word-of-mouth much more efficient and observable.

Moreover, wireless and mobile systems allow people to share more easily their experiences in the online environment (Buhalis and Law, 2008; Inversini et al., 2010). It follows that consumers have increased the action of posting their comments in online environments (Kim et al., 2015b).

Recent studies have identified two different kinds of online/electronic WOM (eWom): "organic/intrinsic" and "amplified/extrinsic" (also called "exogenous WOM"). In the first case WOM occurs spontaneously by the customer while, in the second case, the company stimulate customers to hasten the spread of WOM (Godes and Mayzlin, 2004; Libai et al., 2010).

The perception of eWOM credibility is affected by informative cues, such as argument strength and source credibility (Zhang and Watts, 2008; Cheung et al., 2009) and by normative cues, i.e., recommendation consistency and recommendation rating (Cheung et al., 2009). Consumers use these cues to determine if eWOM is trustable.

\section{eWOM impacts on purchases}

Electronic word-of-mouth (eWOM) has an impact on customer attitudes and consequently on booking/purchase intentions (Park et al., 2007; Doh and Hwang, 2009; Ladhari and Michaud, 
2015; Book et al., 2015). Some studies in the marketing field demonstrate that companies' financial performance can be affected by online reviews (Chevalier and Mayzlin, 2006; Liu, 2006; Dellarocas et al., 2007; Cheung et al., 2009). The same topic has been examined in relation to the service sector and especially with respect to the hospitality sector. Research shows that online content and recommendations generally inform searching, travel planning and purchase decisions (Gretzel and Yoo, 2008; Litvin et al., 2008; Papathanassis and Knolle, 2011; Vermeulen and Seegers, 2009; Ye et al., 2009 and 2011). According to a study on the state of social media (Nielsen, 2013), 70\% of the interviewed consumers indicated they trust online consumer reviews. A relevant research question concerns the ability of online reviews to communicate actual product quality. People who post online feedback had generally extreme positive or negative experiences (Litvin et al., 2008). In particular, Anderson (1998) showed that extremely dissatisfied customers produce greater word-of-mouth than very satisfied customers. On the contrary, customers who underwent moderate experiences are less interested in reporting their perceptions online (under-reporting bias) (Hu et al., 2009). Nevertheless, a study by Banerjee and Fudenberg (2004) suggests that the reporting-bias tendency to post extreme ratings rather than average ones does not lessen the effect of WOM for perfect social learning. Consumers tend to average these extreme ratings when making judgments and this average is close to the real quality of the product. Another criticism involves online reviews reporting subjective evaluations and perceptions of quality by consumers (consumer bias). This is especially true in cases of one-dimensional ratings that do not allow for differentiating the evaluation of various dimensions of quality (Ye et al., 2014). This perception of bias can affect the credibility and effectiveness of eWOM. However, also in this case, previous research 
(Banerjee and Fudenberg, 2004; Hu et al., 2009) suggests that online users of social media are generally smart and aware of these biases and look for multiple sources.

Especially in online complex decision-making processes, consumers rely on information that is accessible and easy to process (Sparks and Browning, 2011). Purchases in the hotel industry are subject to product uncertainty and to asymmetric information, due to the impossibility to evaluate hotel performance before consumption (Ba and Pavlou, 2002). The concept of asymmetric information goes back to Akerlof (1970), who clarified how the scarcity of information of a buyer compared to a seller creates uncertainty regarding a product.

In order to cope with this uncertainty, consumers evaluate several attributes and consult diverse information sources to assess the credibility of the message (Jun et al., 2007; Nicolau and Sellers, 2010). In particular, dual process theory (Cheung et al., 2009) considers how information contained in the message (central route factors) and online social mechanisms (peripheral route factors) can affect the persuasiveness of online recommendations. Despite reading reviews may help customers in their choice process (Dellarocas, 2003), information search is an activity that is both costly and time consuming. For these reasons, consumers are inclined to use numerical ratings which are easy to process. In a recent study that tested for several dimensions of online reviews, the impact of numerical cues was shown to be predominant (Zhao et al., 2015).

As central factors such as information contained in the review and review depth are less relevant for experience products in light of the high subjectivity of the message (Mudambi and Schuff, 2010), for the purpose of this study we decided to investigate the first stage of the decision: peripheral route information processing.

The hypotheses of our study are explored in detail below. 
Hypotheses development

The present study wants to investigate the association between some peripheral cues used by consumers and hotel occupancy by testing the impact of product ratings, eWOM consistency (the variance of consensus about a product), and eWOM volume. The conceptual model is illustrated in Figure 1.

\section{[INSERT FIGURE 1 HERE]}

The average score contributes to the creation of a ranking that in hospitality, according to Filieri and McLeay (2014), is considered one of the most relevant antecedents of information adoption. Customer rating dynamics have a direct effect on product sales (Moe and Trusov, 2011), therefore they can significantly increase hotel online sales and pricing (Öğüt and Onur Taş, 2012), making online transactions less risky (Ba and Pavlou, 2002). With respect to star rating, online customer rating is increasingly considered by potential consumers as a signal of quality (Öğüt and Onur Taş, 2012). This implies that online customer rating might be strongly associated tp hotel occupancy. Therefore our first hypothesis suggests a relationship between this eWOM dimension (score) and hotel occupancy rate:

H1: The higher the online review scores, the higher the hotel occupancy will be.

Another component of online reviews is recommendation consistency, i.e., the level of variance of opinions about a product (Ye et al., 2009; Moon et al., 2010; Sun, 2012). The consensus taken from reviews on the topic, coming from the balance of positive and negative comments, enables potential consumers to more confidently consider each alternative (Tsao et al., 2015). 
Sun (2012) suggests that a high standard deviation in book ratings is strongly related to lower book sales. Similar findings are found in the movie industry (Moon et al., 2010) and in the hospitality industry (Ye et al., 2009). Nonetheless, Kim et al. (2015a) did not find a significant effect of the standard deviation of overall ratings on hotel performance.

Considering these contrasting results, an interesting point is investigating if the variation of opinions has an effect on hotel occupancy. The general theoretical framework makes clear that consumers rely on reviews to reduce uncertainty and to find credibility signals. The argument presented here is that substantial variability in the message does not solve this uncertainty. Therefore this research suggests that:

H2: The higher the variance of opinions, the lower the hotel occupancy will be.

Volume is another dimension of eWOM. It is generally analysed through the number of reviews posted by consumers on a particular product, company, brand or destination (Godes and Mayzlin, 2004). If consumers find a greater number of reviews they could infer that lots of people have purchased the product (Park et al., 2007), and therefore reduce feelings of anxiety when making a purchase decision (Chatterjee, 2001). A higher quantity of online reviews has a positive influence on customers' perceived credibility (Fan et al., 2013) and is generally associated with a higher probability to find the kind of information the consumer is seeking (Filieri, 2015). This dimension is considered in different ways depending on the kind of traveller (novices vs experts) (Park et al., 2007), and the types of segments (Blal and Sturman, 2014). Nonetheless, there is an on-going debate in the literature as to whether the number of reviews plays an active role in the decision-making process and purchasing decisions. On the one hand, 
according to the findings of Filieri and McLeay (2014), the traveller does not take online review quantity into account during the decision-making process. Similarly, Kim et al. (2015a) show how the volume of reviews does not have a global effect on hotel performance (measured as ADR and RevPar).

On the other hand, review volume was shown to increase the awareness of the product, with the effect of positively influencing product popularity and sales (Chevalier and Mayzlin 2006, Liu 2006, Duan et al., 2008), sometimes even in the case of negative reviews (Vermeulen and Seegers 2009; Viglia et al. 2014). This implies that review volume will boost the level of occupancy, regardless the score of the review. Social norms might explain this phenomenon, as an alternative might be considered attractive just because it is popular.

The volume of reviews should be related to hotel performance, when measured by means of occupancy rates, but only within certain boundaries. More precisely, we posit that he number of reviews is a crucial variable taken into account by the consumer but when many reviews are already present the effect of additional reviews is only marginal (i.e. decreasing effects). Therefore we posit that:

H3a: Regardless the score of the review, the higher the number of reviews (volume), the higher the hotel occupancy will be.

H3b: The impact of the number of reviews (volume) on occupancy rates decreases as the number of reviews increases (decreasing returns).

Other factors 
Other factors affecting hotel occupancy rates can be considered by travellers during the decision process and are included in our empirical model as control variables.

A first factor is hotel rate (price). Ye et al. (2014) examined how product price influences postpurchase perceptions and in turn consumer reviews. Li and Hitt (2010) conceptualized this phenomenon suggesting that consumer benefits come from the difference between the utility derived from product quality and the actual price paid. It follows that a company, by simply reducing its price level, can increase its occupancy.

Another factor to be considered is hotel category (e.g., star rating) established by local authorities to evaluate hotel quality. Some studies have demonstrated a lack of correspondence between star rating and the actual quality offered by the hotel according to customer expectations (Lopez Fernandez and Serrano Bedia, 2004). Nonetheless, star rating can be related to hotel performance indicators. While it is known that the level of the category implies a different customer' expectation and different prices (Zhang et al., 2011; Ariffin and Maghzi, 2012; Ye et al., 2014), the effect of star rating on occupancy is almost unexplored. The only study that measures this is the one of Öğ̈̈t and Onur Taş (2012), which presents star rating and online reviews as similar constructs of quality. Showing that having a high star rating does not drive hotel occupancy, the authors conclude that eWOM is the most effective measure to increase sales.

Belonging to a hotel chain could be another factor that increases hotel occupancy. Hotel chains have a well-known brand and can invest more money in marketing and technological tools (e.g., loyalty schemes, a centralized booking engine, etc.), influencing the awareness of the product with the final effect of driving sales (O'Neill and Mattila, 2010). This result deserves further 
investigation as some chains were shown to be ineffective in bringing value (O'Neill and Xiao, 2006).

Other factors should be considered when analysing hotel occupancy. The location of the hotel, either in terms of urban and suburban dimension or in terms of city specificity, is found to influence financial performance (Ye et al., 2009; Blal and Sturman, 2014). Finally, some seasonality effects might drive hotel occupancy (Sourouklis and Tsagdis, 2013).

\section{Empirical study}

The main objective of the study is to identify, through regression analysis, $H 1, H 2, H 3 a$ and $H 3 b$, i.e., the effects of the different dimensions of online reviews on occupancy rates.

\section{Sample}

The empirical case presented in this research is based on occupancy rates, online consumer reviews and other control variables for 346 hotels located in the city centre of Rome, a popular travel destination in Europe.

Two independent data sources were utilised. The first dataset contains occupancy rates obtained directly by contacting the 956 hotels present in the city centre of Rome (EBTL, 2014). Of the total number of hotels, 346 consented to give us information about their occupancy rates in terms of sold rooms. This implies a response rate of $36 \%$. We ensured hotels that responses would only be presented at aggregate level. Table 1 compares the final sample of hotels that took part in the analysis to the total population of hotels in Rome. In our sample, we had no hotels of one-star rating. The problem of retrieving data from one-star hotels is well documented in the literature (Phillips et al., 2015) and might be due to the scepticism of these hoteliers to 
give information for research purposes. Aside from this, there is no apparent selection bias for the sample of two to five-star hotels.

\section{[INSERT TABLE 1 HERE]}

Our second dataset includes online customer review ratings for the 346 hotels. It consists of a complete set of consumer ratings obtained from the three most influential online travel review websites in Italy, namely Booking.com, TripAdvisor and Venere.com (Ali, 2014). All these review websites require the consumer to assign an evaluation score of his/her experience (along various dimensions such as cleanliness, service, etc.), and have a scale of evaluation between 2.5 and 10 (Booking.com), between 1 and 5 (TripAdvisor) or between 1 to 10 (Venere.com). For the sake of homogeneity, all the scores were converted into a 1-10 scale with the following transformation for each rating of Booking.com and TripAdvisor $\left(\mathrm{x}_{i}\right)$ in the dataset: $\left(\mathrm{V}_{\max }{ }^{-}\right.$ $\left.\mathrm{V}_{\text {min }}\right) *\left(\mathrm{x}_{i}-\mathrm{V}_{\text {min }}\right) /\left(\mathrm{v}_{\text {max }}-\mathrm{V}_{\text {min }}\right)+\mathrm{V}_{\text {min }}$, where $\mathrm{V}_{i}$ are the values in the transformation scale (1-10), $\mathrm{x}_{i}$ is

the empirical value to be transformed, and $\mathrm{v}_{i}$ are the values in the original scale (1-5). This method adapted from IBM (2010) allows all the three variables to have an equal range. These variables were then combined by means of a weighted average based on the popularity of these online travel review websites in Italy, as provided by the competitive intelligence metrics service SimilarWeb (Ali, 2014). This second dataset also includes the variability of the ratings in terms of review score as in Ye et al. (2009), and the total number of reviews, as in Kim et al. (2015a). The measurement of the variability of the reviews was derived by calculating the total review variance for each hotel $i$ as the sum of the variance within each single online travel review website for that hotel $i$ and the variance between online travel review websites for that hotel $i$. The same weighted average, based on the popularity of the 3 online travel review websites, was used to obtain the average number of reviews for each hotel $i$. 
The average number of days between booking date and check-in date ranges from 14 to 21 days (Liu et al., 2014). For this reason, first we collected the average rate and the three dimensions of reviews at hotel level for the last 15 days of October 2014 and, second, we asked hotels to provide us with the occupancy rates of November 2014. The monthly occupancy rate in November 2014 for each hotel in the competitor set is the level at which we have the hotel data. As discussed in the theoretical part of this research, occupancy is related to a combination of several factors such as price, star rating, chain membership, location and seasonality. Considering our specific setting, there is no great variability in terms of location and seasonality but rather high variation in price, star rating and chain membership. For this reason, we collected these three factors and included them as control variables. Table 2 presents the definition and the descriptive statistics of the variables included in the analysis.

[INSERT TABLE 2 HERE]

\section{Analysis}

Since occupancy rates are bound within $[0,1]$ intervals, the ordinary linear regression model might not be appropriate for these kinds of data. However, the dependent variable does not exhibit zero or one values and ranges between 0.29 and 0.9. The Shapiro-Wilk test shows that the occupancy rates are normally distributed. An exploratory quantile regression analysis between review score and occupancy rate did not detect heterogeneity in the impact of the review scores for different levels of occupancy rate. Thus, OLS can be used to estimate the occupancy equations.

The initial empirical model adopted is presented in Equation [1]. Because the relation between online reviews and occupancy rates is close to logarithmical, we use the log values for number 
of reviews. In this way, the dependent variable (occupancy rate) is kept in its original scale. Equation [2] presents the same initial model, but accounting for quadratic effects of the number of reviews, in order to test hypothesis 3b. Finally, Equation [3] introduces the other factors (i.e. star, price, chain) that can influence the occupancy rate. Specifically, star is coded as a dummy that has a value of 0 if the star rating is two or three and a value of 1 if the star rating is four or five. Price is included in the log form to linearize the relationship between price and occupancy, as the impact of prices on occupancy decreases for high levels of the variable. The research also measures a possible interaction effect between price and star rating in terms of occupancy rates, as highlighted in the theoretical part of this research. Chain membership is coded 1 if the hotel is affiliated to a franchise brand and 0 otherwise.

Occupancy Rate $_{i}=\beta_{0}+\beta_{1}$ ReviewScore $_{i}+\beta_{2}$ StDevReview $_{i}+\beta_{3} \log \left(\right.$ Number Of Reviews $\left._{i}\right)+\varepsilon_{i}$ [1]

Occupancy Rate $_{i}=\beta_{0}+\beta_{1}$ ReviewScore $_{i}+\beta_{2}$ StDevReview $_{i}+\beta_{3} \log \left(\right.$ Number Of Reviews $\left._{i}\right)+$ $\beta_{3} \log (\text { Number Of Reviews })^{2}+\varepsilon_{i}$

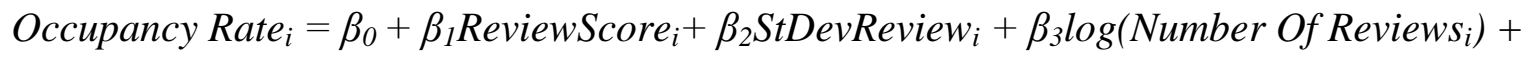
$\beta_{4} \log (\text { Number Of Reviews })^{2}+\beta_{5} \log \left(\right.$ Price $\left._{i}\right)+\beta_{6}$ Star $_{i}+\beta_{7}$ Star $^{*} \log \left(\right.$ Price $\left._{i}\right)+\beta_{8}$ Chain $_{i}+\varepsilon_{i}$ [3]

\section{Hypotheses testing}

Table 3 shows the estimated coefficients of Models 1-3.

[INSERT TABLE 3 HERE] 
Among the three elements of online reviews, review score $\left(\beta_{1}\right)$ has the most significant effect on occupancy $(p<0.001)$. The coefficient associated with the review score suggests that a one point increase in the 1-10 average review score across online platforms is associated to an occupancy boost of 9 percentage points, fully supporting $H 1$. Contrarily to expectations, $H 2$ does not find support, as the standard deviation of the reviews $\left(\beta_{2}\right)$ did not have a significant effect on occupancy. $H 3 a$ is verified by the data, as a higher number of reviews $\left(\beta_{3}\right)$ are associated with higher hotel occupancy.

The second model unpacks the impact of the number of reviews for different levels of the variable. The impact of the number of reviews is positive in both Model 1 and Model 2, but in Model 2 the significant negative coefficient associated to the squared of the log of number of reviews $(-0.174, p<0.05)$ indicates that the impact of the number of reviews decreases for high levels of the variable, as predicted by $H 3 b$. The adjusted $R^{2}$ squared of these models suggests that almost $40 \%$ of the variation in Occupancy Rates (37.2 and 39.1, respectively) is explained by these variables.

As for Model 3, the extended model that accounts for the control variables, review score is still associated to a 7.5 boost in occupancy. As might be expected, $\log ($ Price $)$ has a significantly negative impact on the number of online booking levels $(-0.088, p<0.01)$. Being a 2 or 5 star hotel has a negative effect on occupancy rates $(-0.159, p<0.01$ and $-0.094, p<0.10$, respectively). This suggests that increasing the star rating does not have a direct association with occupancy levels. The positive interaction between $\log ($ Price) and Star $(0.031, p<0.01)$, suggests that consumers are willing to book a hotel that costs more, but only if the star rating is high. 
To better disentangle the effect of star rating and review score on occupancy, Figure 2 presents the effect of review score on occupancy for different levels of star rating.

\section{[INSERT FIGURE 2 HERE]}

In Figure 2 it can be seen how the variable review score has a strong relation to occupancy rates for the different levels of star rating. Interestingly, there are some differences on this impact across levels of star rating. For instance, a two and a five star hotel with a low review score are penalized more in terms of occupancy than other hotel belonging to a different star rating group. The adjusted $R^{2}$ of Model 3 highlights that when adding our control variables, the regression is able to improve its performance by explaining the $53.5 \%$ of the variation in the occupancy rate. Multicollinearity was checked. No significant multicollinearity problem existed, based on the variance inflation factor (VIF) as its values ranged from 1.02 to 2.61 , well below the common threshold of 10 (Hair et al. 1992).

\section{Discussion and conclusions}

\section{Conclusions}

A salient contribution of this research comes from measuring the relation between online usergenerated reviews and a dimension of business performance (hotel occupancy) that is relevant because of the intrinsic nature of this perishable asset (Bilotkach et al., 2015). This study makes use of comprehensive data coming from different types of hotels and multiple online review platforms to improve the validity and generalizations of the findings.

By increasing the number of online review platforms, results are more accurate as different platforms are able to capture diverse groups of hotel guests (Kim et al., 2015a) and even the same customers are generally looking for multiple cues before making a purchase (Noone and McGuire, 2013). 


\section{Theoretical implications}

This study shows the association between online reviews and hotel occupancy providing theoretical and practical knowledge on this topic. In particular, the main result is that a one point increase in the converted 1-10 average review score across online platforms is associated to an increase in the occupancy rate of 7.5 percentage points. This suggests the inclusion of online review considerations in established models of hotel profitability, such as the one of Sainaghi (2010). The findings contribute to the existing literature on eWOM by analysing a less explored hotel performance indicator (hotel occupancy) by means of a comprehensive methodology that considers different kinds of hotels and various online review sources.

A major finding of the study is that the crowd (i.e., the number of reviews) is relevant for lower values of the variable and regardless the score of the review. This suggests that popularity per se has a strong relevance in terms of social preferences.

Another contribution is suggesting that eWOM and star rating are two completely separate constructs of quality, as star rating, which appears to justify different price levels, is not clearly associated to occupancy. This last result opens new theoretical challenges for the current literature that has theorized eWOM rating and star rating as similar measures of quality (Öğ̈̈t and Onur Taş 2012).

Our findings suggest that the number of reviews do count for hotels with a small number of reviews, implying that credibility issues might arise if the hotel has very few reviews. This result reconciles past contrasting findings on the impact of the number of consumer reviews (Ye et al., 2009; Blal and Sturman, 2014; Viglia et al., 2014; Kim et al., 2015a). 
Surprisingly, no effect between the variability of consumer reviews and hotel occupancy rates are observed. Interestingly, by looking at the hospitality literature, Ye et al. (2009) found a significant effect of variance while more recent literature does not consider the effect (Blal and Sturman, 2014) or does not find any effect (Kim et al., 2015a). This recent shift towards the low relevance of variance in online reviews might be explained by the presence of multiple platforms with an increased complexity for the consumer to account for variability of reviews within the same online review platform and between online review platforms. Another possible explanation is that a small degree of variance between positive and negative reviews might even reduce the consumer perception of possible suspicious behaviour of hotels to influence the message (Doh and Hwang, 2009). In sum, moderate review variability should not be a source of great concern for hotels.

\section{Practical implications}

Research portrays that the social media strategy is hardly integrated with the general business strategy of a company (Law and Jogaratnam, 2005; Law et al., 2008), despite such integration would be beneficial (Viglia, 2014; Minazzi, 2015) Web 2.0 now offers firms a large amount of data to improve customer profiling. eWOM is a viable alternative to the engagement of an expensive process aimed at upgrading the star rating. This latter quality certification in fact does not appear per se to have a clear impact in terms of hotel occupancy, at least for 3, 4 and 5 star hotels.

The boost in terms of occupancy given by a unit increase of the online review score is of the same positive sign and comparable in absolute terms with the ones from Anderson (2012) and Kim et al. (2015a). These findings were robust across independent hotels and hotel chains. One 
recent study measures the effect of investing in e-commerce for the individual performance of hotels (Hua et al., 2015). These results suggest that an investment to manage user-generated online content is of paramount importance in the hotel sector. Hotel managers may implement an online reputational management system in order to actively monitor the hotel's reputation to timely spot emerging criticisms in online consumer reviews. A well integrated communication strategy can help hoteliers to create a direct relationship with consumers and prospects before, during and after the trip, stimulating a sharing activity of user-generated content (Mangold and Fauld, 2009; Noone et al., 2011; Kimes, 2011).

Considering the positive relation between the number of reviews and hotel occupancy, hotels should designate staff members to increase the awareness of the hotel especially when the number of reviews is below the average of the market.

\section{Limitations and suggestions for future research}

This study is not without limitations. The main limitation of the study is that, due to difficulty with retrieving individual occupancy data, it explores only one city in detail. By controlling for the level of prices as in Ye et al. (2009), this paper makes use of an output occupancy, which does not incorporate price levels. Using other common financial hospitality metrics, RevPar and ADR, would have allowed measuring the impact in terms of actual profit but it would have created issues of multicollinearity with price levels.

This paper proposes the association between several dimensions of online consumer review and occupancy rates without claiming causation. There is an inherent difficulty in establishing causality between WOM and purchases. Purchases could be higher as a result of the product's quality, which eventually increases the online consumer review ratings. Eliashberg and Shugan 
(1997) bring out this aspect and indicate that online reviews are predictors rather than influencers of product sales. In further studies it would be interesting to test whether reviews are a function of price or independent from it, which would have different consequences for hotel dynamic pricing strategies. If they are independent, hotels can raise prices if they get good reviews without losing consumers; if not, hotels should be more cautious with respect to changing prices. Future research can also go beyond longitudinal data, testing the influence of online review information at $t$ - 1 with those at $t$-2 and identifying exactly which period of online reviews has more effect on hotel performance at time $t$.

\section{References}

Akerlof, G.A. (1970), "The market for "lemons": Quality uncertainty and the market mechanism", The quarterly journal of economics, Vol. 83 No. 3, pp. 488-500.

Ali, R. (2014), “The Most Popular Online Booking Sites in Travel”, 2014 Edition. [online] Skift, available at: http://skift.com/2014/06/17/the-most-popular-online-booking-sites-in-travel2014-edition/ [accessed 19 Sep. 2014].

Anderson, C.K. (2012), "The impact of social media on lodging performance", Cornell Hospitality Report, Vol. 12 No. 5, pp. 4-12.

Anderson, E.W. (1998), "Customer satisfaction and word of mouth", Journal of Service Research, Vol. 1 No. 1, pp. 5-17.

Ariffin, A.A.M. and Maghzi, A. (2012), “A preliminary study on customer expectations of hotel hospitality: Influences of personal and hotel factors", International Journal of Hospitality Management, Vol. 31 No. 1, pp. 191-198. 
Ba, S., and Pavlou, P.A. (2002), "Evidence of the effect of trust building technology in electronic markets: Price premiums and buyer behaviour", MIS quarterly, 243-268.

Banerjee, A. and Fudenberg, D. (2004), "Word-of-mouth learning", Games and Economic Behavior, Vol. 46, pp. 1-22.

Bilotkach, V., Gaggero, A.A. and Piga, C.A. (2015), "Airline pricing under different market conditions: Evidence from European Low-Cost Carriers", Tourism Management, Vol. 47, pp. 152-163.

Blal, I. and Sturman, M.C. (2014), "The differential effects of the quality and quantity of online reviews on hotel room sales", Cornell Hospitality Quarterly, Vol. 55 No. 4, pp. 365-375.

Book, L.A., Tanford, S., Montgomery, R. and Love, C. (2015), “Online traveler reviews as social influence. Price is no longer king”, Journal of Hospitality \& Tourism Research, Published online before print July 30, 2015, doi: 10.1177/1096348015597029.

Buhalis, D. and Law, R. (2008), "Progress in information technology and tourism management: 20 years on and 10 years after the Internet-the state of eTourism research", Tourism Management Vol. 29 No. 4, pp. 609-623.

Buttle, F. (1998), "Word of mouth: understanding and managing referral marketing", Journal of Strategic Marketing, Vol. 6 No. 3, pp. 241-254.

Chatterjee, P. (2001), “Online reviews: do consumers use them?", Advances in Consumer Research, Vol. 28, pp. 129-133.

Cheung, C.M. and Thadani, D.R. (2012), "The impact of electronic word-of-mouth communication: A literature analysis and integrative model", Decision Support Systems, Vol. 54, pp. 461-470. 
Cheung, M.Y., Luo, C., Sia, C.L. and Chen, H. (2009), "Credibility of electronic word-ofmouth: informational and normative determinants of on-line consumer recommendations", International Journal of Electronic Commerce, Vol. 13 No. 4, pp. 9-38.

Chevalier, J.A. and Mayzlin, D. (2006), "The effect of word of mouth on sales: online book reviews", Journal of Marketing Research, Vol. 43 No. 3, pp. 345-354.

Chintagunta, P.K., Gopinath, S. and Venkataraman, S. (2010), "The effects of online user reviews on movie box office performance: Accounting for sequential rollout and aggregation across local markets”, Marketing Science, Vol. 29 No. 5, pp. 944-59.

Dellarocas, C. (2003), "The digitization of word of mouth: Promise and challenges of online feedback mechanisms", Management science, Vol. 49 No. 10, pp. 1407-1424.

Dellarocas, C., Zhang, X.M. and Awad, N.F. (2007), "Exploring the value of online product review in forecasting sales: the case of motion pictures", Journal of Interactive Marketing, Vol. 21 No. 4, pp. 23-45.

Doh, S.J. and Hwang, J.S. (2009), "How consumers evaluate eWOM (electronic word-of-mouth) messages", Cyberpsychology \& Behavior, Vol. 12 No. 2, pp. 193-197.

Duan, W., Gu, B. and Whinston, A.B. (2008), "Do online reviews matter?-An empirical investigation of panel data", Decision Support Systems, Vol. 45 No. 4, pp. 1007-16.

EBTL (2014), “Analisi della domanda turistica negli esercizi alberghieri di Roma e provincia anno 2014", Il Turismo in Cifre. [online] Rome, pp.1-36, available at: http://www.ebtl.it/roma-e-lazio/anno-2013/cat_view/35-osservatorio-roma/217-esercizialberghieri-di-roma-anno-2014/219-analisi-della-domanda-turistica-2014.html [accessed 19 Sep 2014]. 
Eliashberg, J. and Shugan, M. (1997), "Film critics: Influencers or predictors?", Journal of Marketing, Vol. 61, pp. 68-78.

Fan, Y.W., Miao, Y.F., Fang, Y.H. and Lin, R.Y. (2013), "Establishing the adoption of electronic word-of-mouth through consumers' perceived credibility", International Business Research Vol. 6 No. 3, pp. 58-65.

Filieri R., and F. McLeay. (2014). "E-WOM and Accommodation An Analysis of the Factors That Influence Travelers' Adoption of Information from Online Reviews", Journal of Travel Research, Vol. 53 No. 1, pp. 44-57.

Filieri, R. (2015), "What makes online reviews helpful? A diagnosticity-adoption framework to explain informational and normative influences in e-WOM", Journal of Business Research, Vol. 68 No. 6, pp. 1261-1270.

Godes, D. and Mayzlin, D. (2004), "Using online conversations to study word-of-mouth communication”, Marketing Science Vol. 23 No. 4, pp. 545-560.

Gretzel, U., and Yoo, K.H. (2008), "Use and impact of online travel reviews", Information and Communication Technologies in Tourism, Vol. 2, pp. 35-46.

Hair, J.F., Black, W.C., Babin, B.J. and Anderson, R.E. (1992), "Multivariate Data Analysis", Prentice Hall, New York.

Hu, N., Pavlou, P.A. and Zhang, J. (2009), "Overcoming the J-shaped distribution of product reviews", Communications of the ACM, Vol. 52 No. 10, pp. 144-147.

Hua, N., Morosan, C. and DeFranco, A. (2015), "The other side of technology adoption: Examining the relationships between e-commerce expenses and hotel performance", International Journal of Hospitality Management, Vol. 45, pp. 109-120. 
IBM (2010). "Transforming different Likert scales to a common scale", available at: http://www-01.ibm.com/support/docview.wss?uid=swg21482329 (accessed: 30 July 2015).

Inversini, A., Marchiori, E., Dedekind, C. and Cantoni. L. (2010), “Applying a conceptual framework to analyze online reputation of tourism destinations”, in Gretzel, U., Law, R. amd Fuchs, M. (eds.), Information and Communication Technologies in Tourism 2010. Proceedings of the International Conference in Lugano. Switzerland, February 10-12. Springer, Wien-New York, pp 321-332.

Jun, S.H., Vogt, C.A., and MacKay, K.J. (2007), "Relationships between travel information search and travel product purchase in pre-trip contexts", Journal of Travel Research, K.J., Vol. 45 No. 3, pp. 266-274.

Kim, D., Jang, S., and Adler, H. (2015b), "What drives café customers to spread eWOM? Examining self-relevant value, quality value, and opinion leadership", International Journal of Contemporary Hospitality Management, Vol. 27 No. 2, pp. 261-282.

Kim, W.G., Limb, H. and Brymer, R.A. (2015a), "The effectiveness of managing social media on hotel performance", International Journal of Hospitality Management, Vol. 44: pp. 165171.

Kimes, S.E. (2011), “The Future of Hotel Revenue Management”. Journal of Revenue and Pricing Management, Vol. 10 No. 1, pp. 62-72.

Ladhari, R., and M. Michaud (2015). "eWOM effects on hotel booking intentions, attitudes, trust, and website perceptions" International Journal of Hospitality Management, Vol. 46 No. 1, pp. 6-45. 
Law, R., Leung, R. and Buhalis, D. (2008), "Information technology applications in hospitality and tourism: a review of publications from 2005 to 2007”, Journal of Travel and Tourism Marketing, Vol. 26 No. 5, pp. 599-623.

Law, R. and Jogaratnam, G. (2005), "A study of hotel information technology applications". International Journal of Contemporary Hospitality Management, Vol. 17 No. 2, pp. 170180.

Li, X. and Hitt, L.M. (2010), "Price effects in online product reviews: An analytical model and empirical analysis", MIS Quarterly, Vol. 34 No. 4, pp. 809-831.

Libai, B., Bolton, R., Bügel, M.S. de Ruyter, K., Götz, O., Risselada, H. and Stephen, A.T. (2010), "Customer-to-customer interactions: broadening the scope of word of mouth research", Journal of Service Research, Vol. 13 No. 3, pp. 267-282.

Litvin, S.W., Goldsmith, R.E. and Pan, B. (2008), "Electronic word-of-mouth in hospitality and tourism management", Tourism Management Vol. 29 No. 3:pp. 458-468.

Liu, W., Guillet, B.D., Xiao, Q. and Law, R. (2014), “Globalization or localization of consumer preferences: The case of hotel room booking", Tourism Management, Vol. 41, pp. 148-157.

Liu, Y. (2006), "Word of mouth for movies: Its dynamics and impact on box office revenue", Journal of Marketing, Vol. 70, pp. 74-89.

Lopez Fernandez, M.C., and Serrano Bedia, A.M. (2004), "Is the hotel classification system a good indicator for quality? An application in Spain”, Tourism Management, Vol. 25 No. 6, pp. 771-775.

Mangold, W.G. and Faulds, D.J. (2009), "Social media: The new hybrid element of the promotion mix", Business horizons Vol. 52 No. 4, pp. 357-365.

Mauri, A. and Minazzi, R. (2013), "Web reviews influence on expectations and purchasing 
intentions of hotel potential customers", International Journal of Hospitality Management Vol. 34, pp. 99-107.

Minazzi, R. (2015), "Social Media Marketing in Tourism and Hospitality", Springer International Publishing AG, Switzerland.

Moe, W.W. and Trusov M. (2011), "The value of social dynamics in online product ratings forums”. Journal of Marketing Research, Vol. 48 No. 3, pp. 444-456.

Moon, S., Bergey, P.K. and Iacobucci, D. (2010), "Dynamic effects among movie ratings, movie revenues, and viewer satisfaction”, Journal of Marketing, Vol. 74 No. 1, pp. 108-121.

Mudambi, S.M., and Schuff, D. (2010), "What makes a helpful online review? A study of consumer reviews on amazon.com”, MIS Quarterly, Vol. 34 No. 1, pp. 185-200.

Nicolau, J.L. and Sellers, R. (2010), "The quality of quality awards: diminishing information asymmetries in a hotel chain”, Journal of Business Research, Vol. 63 No. 8, pp. 832-839.

Nielsen (2013), "State of the media: the social media report 2012", available via: http://www.nielsen.com/us/en/reports/2012/state-of-the-media-the-social-media-report2012.html, accessed August 2013.

Noone, B.M., McGuire, K.A. and Rohlfs, K.V. (2011), "Social media meets hotel revenue management: Opportunities, issues and unanswered questions", Journal of Revenue and Pricing Management, Vol. 10 No. 4, pp. 293-305.

Noone, B.M. and McGuire, K.A. (2013), "Pricing in a social world: the influence of non-price information on hotel choice", Journal of Revenue Pricing Management, Vol. 12 No. 5, pp. $385-401$.

Ogden, M. (2001), "Marketing truth: hearing is believing”, The Business Journal Vol. 16 No. 52, p.17. 
Öğüt, H. and Onur Taş, B.K. (2012), "The influence of Internet customer reviews on the online sales and prices in hotel industry", The Service Industries Journal, Vol. 32 No. 2, pp. 197214.

O’Neill, J.W. and Xiao, Q. (2006), “The role of brand affiliation in hotel market value”, Cornell Hotel and Restaurant Administration Quarterly, Vol. 47 No. 3, pp. 210-223.

O'Neill, J.W., and Mattila, A.S. (2010), "Hotel brand strategy", Cornell Hospitality Quarterly Vol. 51 No.1, pp. 27-34.

Papathanassis, A., and Knolle, F. (2011), "Exploring the adoption and processing of online holiday reviews: A grounded theory approach”, Tourism Management, Vol. 32 No. 2, pp. 215-224.

Park, D.H., Lee, J. and Han, I. (2007), “The effect of on-line consumer reviews on consumer purchasing intention: the moderating role of involvement", International Journal of Electronic Commerce, Vol. 11 No. 4, pp. 125-148.

Phillips, P., Zigan, K. Silva, M.M.S. and Schegg, R. (2015). “The interactive effects of online reviews on the determinants of Swiss hotel performance: A neural network analysis", Tourism Management, Vol. 50, pp. 130-141.

Sainaghi, R. (2010), "Hotel performance: state of the art", International Journal of Contemporary Hospitality Management, Vol. 22 No. 7, pp. 920-952.

Sourouklis, C. and Tsagdis, D. (2013), "Workforce diversity and hotel performance: A systematic review and synthesis of the international empirical evidence", International Journal of Hospitality Management, Vol. 34, pp. 394-403.

Sparks, B.A. and Browning, V. (2011), "The impact of online reviews on hotel booking intentions and perception of trust". Tourism Management, Vol. 32 No. 6, pp. 1310-1323. 
Sparks, B.A., Perkins, H.E. and Buckley, R. (2013), "Online travel reviews as persuasive communication: The effects of content type, source, and certification logos on consumer behaviour", Tourism Management, Vol. 39, pp. 1-9.

Stern, B. (1994), "A revised model for advertising: multiple dimensions of the source, the message, and the recipient", Journal of Advertising, Vol. 23 No. 2, pp. 5-16.

Sun, M. (2012), “How does the variance of product ratings matter?", Management Science, Vol. 58 No. 4, pp. 696-707.

Tsao, W.C., Hsieh, M.T., Shih, L.W. and Lin, T.M. (2015), "Compliance with eWOM: The influence of hotel reviews on booking intention from the perspective of consumer conformity", International Journal of Hospitality Management, Vol. 46, pp. 99-111.

Vermeulen, I.E. and Seegers, D. (2009), “Tried and tested: the impact of online hotel reviews on consumer consideration", Tourism Management, Vol. 30 No. 1, pp. 123-127.

Viglia, G., Furlan, R. and Ladrón-de-Guevara, A. (2014), "Please, talk about it! When hotel popularity boosts preferences", International Journal of Hospitality Management, Vol. 42, pp. $155-164$.

Viglia, G. (2014), "Pricing, Online Marketing Behavior, and Analytics". Palgrave Macmillan.

Webster, C. (1991), "Influences upon consumer expectations of services", Journal of Services Marketing, Vol. 5, pp. 516-33.

Ye, Q., Law, R. and Gu, B. (2009), "The impact of online user reviews on hotel room sales", International Journal of Hospitality Management, Vol. 28, pp. 180-182.

Ye, Q., Li, H., Wang, Z. and Law, R. (2014), “The Influence of Hotel Price on Perceived Service Quality and Value in E-Tourism An Empirical Investigation Based on Online Traveller Reviews", Journal of Hospitality \& Tourism Research, Vol. 38 No. 1, pp. 23-39. 
Zeithaml, V.A., Berry, L.L. and Parasuraman, A. (1993), "The nature and determinants of customer expectations of service", Journal of the Academy of Marketing Science, Vol. 21 No. 1, pp. 1-12.

Zhang, Z., Ye, Q., and Law, R. (2011), "Determinants of hotel room price: An exploration of travelers' hierarchy of accommodation needs", International Journal of Contemporary Hospitality Management, Vol. 23 No. 7, pp. 972-981.

Zhao, X., Wang, L., Guo, X., and Law, R. (2015). "The influence of online reviews to online hotel booking intentions", International Journal of Contemporary Hospitality Management, Vol. 27 No. 3, pp. 1343-1364.

\section{LIST OF TABLES AND FIGURES}

Figure 1. The conceptual model 


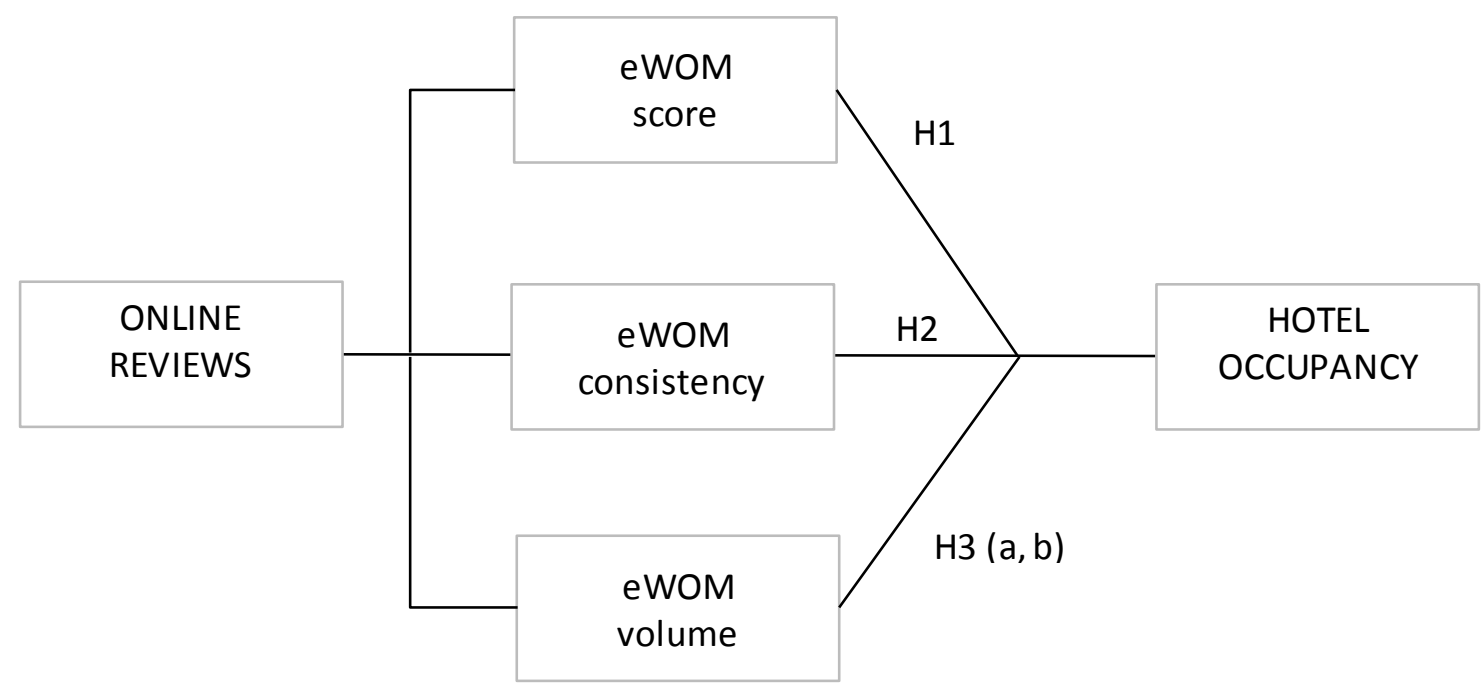

Table 1. Number of hotels and occupancy rates in the sample and Rome average (2014)

\begin{tabular}{lrrrrrr}
\hline Category & No. of hotels in sample & No. of hotels in Rome & $\begin{array}{c}\text { Occupancy } \\
\text { rate in sample }\end{array}$ & $\begin{array}{c}\text { Occupancy rate } \\
\text { in Rome }\end{array}$ \\
\hline 1 star & 0 & $0 \%$ & 32 & $3.3 \%$ & NA & $48.0 \%$ \\
2 star & 53 & $15.3 \%$ & 199 & $20.8 \%$ & $61.4 \%$ & $59.5 \%$ \\
3 star & 160 & $46.2 \%$ & 355 & $37.1 \%$ & $67.8 \%$ & $68.1 \%$ \\
4 star & 103 & $29.8 \%$ & 251 & $26.3 \%$ & $67.6 \%$ & $69.8 \%$ \\
5 star & 30 & $8.7 \%$ & 32 & $3.3 \%$ & $66.3 \%$ & $66.1 \%$ \\
\hline Total & 346 & $100 \%$ & 956 & $100 \%$ & $65.4 \%$ & $62.3 \%$ \\
\hline
\end{tabular}

Table 2. Variable taxonomy

\begin{tabular}{lllcc}
\hline Type of Variable & Variable & Description & Average & Sd \\
\hline Core & Occupancy rate & Average room occupancy & 0.65 & 0.16
\end{tabular}




\begin{tabular}{|c|c|c|c|c|}
\hline & (dependent variable) & $\begin{array}{l}\text { for each } \\
\text { hotel } i \text { in November } 2014\end{array}$ & & \\
\hline & Review Score & $\begin{array}{l}\text { Weighted average review } \\
\text { score (booking.com, } \\
\text { tripadvisor, venere.com) }\end{array}$ & 7.75 & 0.92 \\
\hline & StDev Review & $\begin{array}{l}\text { Squared root of the total } \\
\text { variance of scores (within } \\
\text { online travel agent and } \\
\text { between online travel } \\
\text { agents) for hotel } i\end{array}$ & 2.41 & 1.03 \\
\hline & Number of Reviews & $\begin{array}{l}\text { Average number of reviews } \\
\text { for each hotel } i\end{array}$ & 195.55 & 107.29 \\
\hline Control & Price & $\begin{array}{l}\text { The average lowest price of } \\
\text { a single hotel room across } \\
\text { online travel agents }\end{array}$ & 133.27 & 58.62 \\
\hline & Star & $\begin{array}{l}\text { A dummy variable that } \\
\text { equals } 0 \text { if the hotel has two } \\
\text { or three stars according to } \\
\text { an official organization } \\
\text { regarding the quality of the } \\
\text { hotel and } 1 \text { if the hotel has } \\
\text { four or five stars }\end{array}$ & 0.39 & \\
\hline & Chain & $\begin{array}{l}\text { A dummy variable that } \\
\text { denotes the hotel is part of a } \\
\text { chain company }\end{array}$ & 0.38 & \\
\hline
\end{tabular}

Chain is a dummy variable presented in percentage. Prices are in $\epsilon$.

Table 3. OLS estimates of the determinants of the occupancy rate (Models 1-3) 


\begin{tabular}{|c|c|c|c|}
\hline Variables & $\begin{array}{c}\text { (1) } \\
\text { Occupancy } \\
\text { Rate }\end{array}$ & $\begin{array}{c}(2) \\
\text { Occupancy } \\
\text { Rate }\end{array}$ & $\begin{array}{c}\text { (3) } \\
\text { Occupancy } \\
\text { Rate }\end{array}$ \\
\hline Review Score & $\begin{array}{c}0.090 * * * \\
(0.007)\end{array}$ & $\begin{array}{c}0.089 * * * \\
(0.007)\end{array}$ & $\begin{array}{c}0.075 * * * \\
(0.007)\end{array}$ \\
\hline StdDevReview & $\begin{array}{l}-0.001 \\
(0.001)\end{array}$ & & \\
\hline Log(NumberOfReviews) & $\begin{array}{c}0.079 * * * \\
(0.010)\end{array}$ & $\begin{array}{c}0.421 * * * \\
(0.087)\end{array}$ & $\begin{array}{c}0.402 * * * \\
(0.083)\end{array}$ \\
\hline (LogNumberOfReviews) $)^{2}$ & & $\begin{array}{c}-0.170 * * * \\
(0.043)\end{array}$ & $\begin{array}{c}-0.165 * * * \\
(0.041)\end{array}$ \\
\hline $\log ($ Price $)$ & & & $\begin{array}{c}-0.080 * * * \\
(0.020)\end{array}$ \\
\hline 2 Stars & & & $\begin{array}{c}-0.158^{* * *} \\
(0.047)\end{array}$ \\
\hline 4 Stars & & & $\begin{array}{l}-0.0120 \\
(0.018)\end{array}$ \\
\hline 5 Stars & & & $\begin{array}{l}-0.094 * \\
(0.052)\end{array}$ \\
\hline Star*log(Price) & & & $\begin{array}{c}0.031 \text { *** } \\
(0.009)\end{array}$ \\
\hline Chain & & & $\begin{array}{c}0.005 \\
(0.012)\end{array}$ \\
\hline Constant & $\begin{array}{c}-0.520^{* * *} \\
(0.076)\end{array}$ & $\begin{array}{c}-0.522 * * * \\
(0.074)\end{array}$ & $\begin{array}{c}0.031 \\
(0.132)\end{array}$ \\
\hline Observations & 346 & 346 & 346 \\
\hline R-squared & 0.372 & 0.391 & 0.535 \\
\hline
\end{tabular}

OLS with heteroscedasticity consistent standard errors

In Model 3, 2 Stars, 4 Stars and 5 Stars are dummy

variables and their coefficients have to be interpreted as

differentials from the baseline (3 Stars).

Standard errors in parentheses

$* * * p<0.01, * * p<0.05, * p<0.1$

Figure 2. The impact of review score on occupancy rate controlling for the levels of star rating 


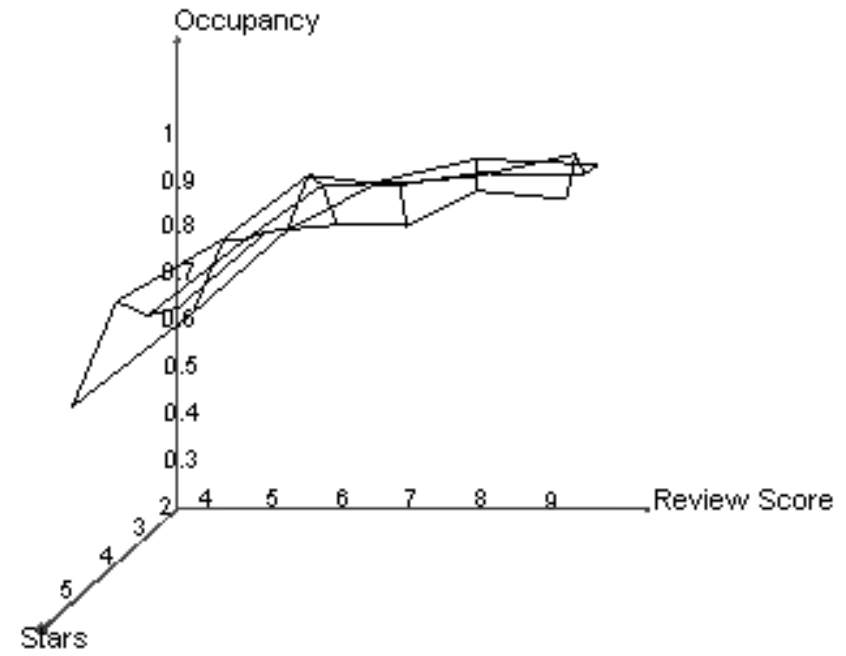

